\title{
FACING INCREASED RUSSIAN AGGRESSIVENESS: POPULAR MILITIAS, A POTENTIALLY EFFECTIVE EXTRA POLITICAL AND MILITARY INSTRUMENT AIMED AT STRATEGIC DETERRENCE
}

\author{
Florin DIACONU, Ph.D. \\ Faculty of Political Science \\ University of Bucharest, Romania \\ florin.diaconu@fspub.unibuc.ro
}

\begin{abstract}
The text starts by briefly exploring the present strategic situation on NATO's Eastern rim. In a situation clearly dominated by sharply increased Russian aggressiveness, and by the fact that Russia has already made several attempts directly aimed at shaping, by force, a new regional and continental balance of power (see war against Georgia, in 2008, the annexation of Crimea, in 2014, and an extensive set of military actions against Ukraine), Russian plans and actions are legitimately worrying NATO and, above all, the small or medium-sized countries on the Eastern border of the North Atlantic Alliance. Starting mainly in 2014, Russian aggressiveness generated some significant reactions within NATO, including the political decision to increase defence budgets and deploying (mainly by rotation) military forces belonging to Western member states in the directly threatened countries. These countries (the three small Baltic republics, Poland and Romania) are also strengthening their defensive capabilities, buying new weapons systems, and by hosting or organising NATO defensive exercises. But all these deterrents are costly, and implementing them is time-consuming. It is for these reasons that the article examines the politicalstrategic necessity of implementing national policies aimed at quickly generating and consolidating potent popular militias. These militias, which are an obvious embodiment of a very strong political will at national level, might be, if properly used, an extra significant deterrent, directly telling Putin's regime it has no real chance of winning a quick and cheap victory, if it behaves aggressively against states on the Eastern rim of NATO.
\end{abstract}


At this very moment, more than ever before (at least for the almost 30 years since the end of the Cold War), NATO is confronted with the openly aggressive foreign policy, strategic plans and strategic actions of the Russian Federation.

Key words: Russia; imperial expansionism; NATO; strategic deterrence; political will; effectiveness; balance of power; popular militia

\section{Some features of the present strategic situation on the Eastern rim of NATO}

For almost one generation, NATO has officially relied, when dealing with Russia, on what we can legitimately call a grand strategic illusion (or, in order to use a concept from political science, in political \& military history, and in strategic studies, a massive amount of wishful thinking).

Starting with the early 1990s, important NATO official and public documents almost completely ignored the existence, the real nature and the significant intensity of long-term threats generated by more or less perennial ${ }^{1}$ Russian expansionist/ aggressive plans, and by Russia's aggressive actions in the international arena. For example, the new Strategic Concept adopted in November 1991 was exceedingly optimistic (to put it mildly), when it evaluated the general situation in Europe and its future perspectives. According to that document, a "new strategic environment" was the basic feature of major political evolutions in Europe. The Concept stated that "all the countries that were formerly adversaries of NATO have dismantled the Warsaw Pact and rejected ideological hostility to the West" (paragraph 1 of the Concept). It also stated "the political division of Europe that was the source of the military confrontation of the Cold War period has thus been overcome" (paragraph 1 of the Concept). In such a situation, it was quite normal - up to a certain point - to promote a new type of broad relationship with Russia. Over several decades of the Cold War, the bilateral relations of Moscow and the Western World (in which NATO was the most important political-military

1 The clearly perennial nature of the aggressiveness and imperial expansionism of Russia's foreign policy is explored, with a lot of vivid details, for the years immediately after the end of the Cold War, in J. Bugajski, Cold Peace: Russia's New Imperialism, 2004. 
alliance) were dominated, on most occasions, by intense strategic competition, and also by mutual hostility, significantly boosted (or aggravated) by several significant crises $^{2}$, and by several important proxy wars. But if Russia is not any more a foe (or an active source of really major threats and risks), hostility is to be abandoned, which almost openly heralded the Strategic Concept adopted in 1991. According to this NATO document, ideological hostility and intense strategic caution were to be quickly and massively replaced by a new strategic mood, aimed at "a genuine partnership among all European countries" (paragraph 25 of the Concept). The future, NATO leaders publicly stated, was to be one based mainly on "dialogue... with the Soviet Union", including "an intensified exchange of views and information on security policy issues" (Paragraph 28 of the Concept) ${ }^{3}$.

Later on, as the war in Chechnya proved, almost on a daily basis it was very clear that Russia did not really change (if we are speaking about state aggressiveness, and about the lack of any serious inhibition in planning and implementing really atrocious war policies $)^{4}$ at official level, though Russia was regarded by NATO as a partner of the West (and, possibly, as a friend you can really trust).

A broadly friendly political and strategic attitude towards Russia, openly emphasising cooperation and partnership with Moscow is also present in the next Strategic Concept, adopted in 1999. It openly states that the "East-West confrontation" has finally come "to a peaceful end" (Paragraph or Article 2 of the Concept). It also states, optimistically, that we can speak about "increased political and military partnership, cooperation and dialogue with other states, including

2 For the list of major crises between 1948 and 1991 see J.-L.Dufour, Crizele Internaționale De La Beijing (1900) La Kosovo (1999) [International Crises From Beijing (1900) To Kosovo (1999)] 2002, pp. 93-201; most of these crises have been directly associated with the central strategic competition of the Cold War.

3 The Alliance's New Strategic Concept agreed by the Heads of State and Government participating in the Meeting of the North Atlantic Council, 7-8.11.1991, http://www.nato. int/cps/en/natohq/official_texts_23847.htm.

4 In order to better understand Russia's behaviour in Chechnya see, for example, A. Liven, Chechnya: Tombstone Of Russian Power, 1998; see also some significant reactions of important Russian leaders: for example, Boris Yeltsin speaking "of the guilt he feels over the two wars waged by Moscow in Chechnya" - Yeltsin Speaks Of Guilt Over Chechnya, 8.10.2000, http://news.bbc.co.uk/2/hi/europe/961848.stm or Mikhail Gorbachev, when he openly "criticised the West for not being more vocal in opposing Russia's first campaign in Chechnya between 1994 and 1996", and openly spoke about the horrendous "bloodbath... in the Caucasus - Gorbachev Criticises Russian Policy In Chechnya, 4.12.1999, http://news. bbc.co.uk/2/hi/europe/549638.stm. 
with Russia" (Paragraph 12, in the opening stages of Part II of the Concept) 5 . Specifically dealing with the relationship with Russia, the Concept stated "within the framework of the NATO-Russia Founding Act on Mutual Relations, Cooperation and Security, NATO and Russia have committed themselves to developing their relations on the basis of common interest, reciprocity and transparency..." (see Paragraph 36 of the Concept).

Most astonishingly, even the next Strategic Concept (the third we are speaking about here), adopted in 2010, went on with exceedingly optimistic evaluations of the bilateral relations of NATO and Russia, and of the future perspectives of these relations. At the moment when this Concept was adopted, Russia had already abandoned its 'acceptable' mask, deliberately waging a savage war of aggression against Georgia ${ }^{6}$. In spite of this very significant episode, NATO was still officially speaking, in 2010, about a strong partnership with Russia. The Strategic Concept adopted in Lisbon stated that "NATO-Russia cooperation... contributes to creating a common space of peace, stability and security" (Paragraph or Article 33) 7 .

But these Strategic Concepts have also managed to openly address some vitally important problems within the Alliance. One of them is what we usually call the capability gap, separating a very strong U.S. military (a reality based on very large defence budgets) and clearly (and perennially) weaker capabilities of the European segment of the Alliance. Dealing with this problem (which in the end means a weak Europe), the Concept adopted in 1999 openly stated, for example, that there is a clear need to "increase the responsibilities and capacities of the European Allies" (see article 18 of the 1999 Strategic Concept).

Predictably, in a context in which Russia was not regarded any more as an enemy or direct and immediate competitor, NATO has significantly diminished its military capabilities in Europe. Above all, large American forces have been

5 For the fragments quoted here: The Alliance's Strategic Concept Approved by the Heads of State and Government participating in the meeting of the North Atlantic Council in Washington D.C..Press Release NAC-S(99) 65, 24.04.1999, http://www.nato.int/cps/en/ natohq/official_texts_27433.htm.

6 For better understanding, this war which took place in 2008, see R.D. Asmus, A Little War That Shook The World: Georgia, Russia, And The Future Of The West, 2010.

7 Strategic Concept For the Defence and Security of The Members of the North Atlantic Treaty Organisation. Adopted by Heads of State and Government in Lisbon, 2010, http:// www.nato.int/lisbon2010/strategic-concept-2010-eng.pdf. 
brought home, to the U.S., or redeployed to other regions of the world. In such a situation, the strategic balance of power in Europe has dramatically changed, Russia managing to identify a major window of opportunity here: even with clearly limited resources, it might be, in certain circumstances, more powerful, in military terms, than NATO forces immediately and locally available in countries on the Eastern rim of NATO.

\section{The NATO Summit in Wales: even if quite late, NATO decides to react}

Russia has most probably evaluated NATO statements as those already listed above (and the associated policies and actions) as being useful political indicators. The more NATO was talking about partnership and cooperation with Russia, the weaker NATO forces deployed in Europe were becoming. And the weaker NATO military capabilities (and NATO political will, up to a certain point) were, the larger and more attractive became a really important window of opportunity, which Russia massively used in 2014, invading and annexing Crimea, and launching a massive set of military operations (widely accompanied by other disruptive means and methods) against the Eastern regions of Ukraine, where a quite large Russian-speaking population is concentrated.

Fortunately (even if very late, to put it bluntly), NATO swiftly reacted after the invasion and annexation of Crimea. Quite soon, a new Summit took place, in Wales, and a new strategic vision was discussed and officially adopted. The documents adopted in September 2014 are a clear proof that, even if quite late, NATO top leaders managed to properly understand the very nature of Russia's foreign policy and strategic agenda (and managed to understand that Russia - or, better said, Putin's regime - is not a friend or a partner, but an openly aggressive competitor). The 'political mood' of NATO has dramatically changed, under the impact of the overt Russian aggression against Ukraine. NATO leaders stated, on the occasion of the Wales Summit, that “Russia's aggressive actions against Ukraine 
have fundamentally challenged our vision of a Europe whole, free, and at peace"s (Paragraph or Article 1). The same NATO document openly spoke about the need to respond "to the challenges posed by Russia and their strategic implications", by means of a NATO Readiness Action Plan (Paragraph 5 of the document). Later on, NATO and its member states made $a$ lot of effort to implement the decisions adopted in September 2014.

On the other hand, we have to strongly underline, not all the actions of all NATO member states over the past few years are to be regarded as being really sound attempts aimed at blocking and/or deterring Russian aggressiveness. Carefully exploring the history of the past few years, we can easily identify a number of episodes which, properly analysed, are to be understood as being nothing else but elements of bandwagoning policies. In this context, we are using the concept of bandwagoning with the exact meaning present in an already notorious classical work, stating that "bandwagoning refers to alignment with the source of danger"

When we are trying to understand the strategic situation on the Eastern rim of NATO, and the way in which NATO has to react, we have to also take into account that, on quite many occasions (and on increasing scale after the illegal annexation of Crimea), the Russian Federation has 'flexed its military muscles', organising very large military exercises (regarded by analysts as being instruments of strategic intimidation, and also possibly advanced moves within the framework of preparing what could easily be a war of aggression). Very recently, in September 2017, Russia organised, together with Belarus, a large military exercise called Zapad-2017. Reporting on this event, official media in Russia openly stated that "the scale of the exercise and the complexity of tasks to be coped with grows immeasurably", if we compare these military maneuvers with previous ones. Some figures dealing with the military resources used were made public: "about 12,700 officers and men (10,200 in Belarus), 70 planes and helicopters, up to 680 combat vehicles, including about 250 tanks, up to 200 pieces of artillery, multiple rocket launchers and mortars and ten ships". Even if senior Russian officials

8 Wales Summit Declaration Issued by the Heads of State and Government participating in the meeting of the North Atlantic Council in Wales, 5.09.2014, http://www.nato.int/cps/ic/ natohq/official_texts_112964.htm.

9 S.M. Walt, The Origin Of Alliances, 1987, p. 17. 
declared that "Zapad-2017 exercise is purely defence"10, NATO Secretary General Jens Stoltenberg, dealing with the same event, declared that "from previous experiences related to previous exercises, we have every reason to believe it may be substantially more troops participating than the official reported numbers". And the U.S. Army's top commander in Europe, Lt. Gen. Ben Hodges openly emphasised the lack of a decent level of transparency (saying "I've never met in three years a single journalist who's covered a Russian exercise"), and said instead of inviting journalists in order to demonstrate the defensive nature of the exercise, Russia has moved to advanced positions, not far away from its Western borders, roughly 800 tanks "which exist only to attack" ${ }^{11}$. And, predictably, such aggressive Russian actions are also generating NATO reactions of all sorts.

\section{The logic of long-term action: deterring aggression, or at least making it exceedingly difficult and very expensive}

Simply because Russia does have a very long - and significant - tradition of imperial expansion, massively based on significant wars of aggression ${ }^{12}$, and as long as more of its top leaders, including President Putin, had officially declared the collapse of the USSR (nothing else but a newer version of the older Russian Empire, 'clad' in a new ideology, and continuously interested in expanding its sphere of influence, including to the West) to have been "the greatest geopolitical catastrophe" of the 20th century, and also "a real drama"13 (here Putin is deliberately emphasising the collapse of the USSR has left several tens of millions of Russians outside the

10 Zapad-2017 Exercise Puts Russian Army's „Nervous System” To Test, http://tass.com/ defense/966366 [accessed: 19.09. 2017].

11 Teri Schultz, NATO Voices Skepticism Over Size Of Russia's Zapad Military Exercise, 19.09.2017, http://www.dw.com/en/nato-voices-skepticism-over-size-of-russias-zapad-militaryexercise/a-39682346.

12 For this feature of Russian politics see, for example, J.N. Westwood, Endurance And Endeavour: Russian History 1812-1986, third edition 1987, 1988, pp. 23, 37, 64-71, 108110, 133-144 (for the 19th century), etc.

13 Putin said all these on the occasion of his annual state of the nation address to the Parliament, in 2005. See, for example, Putin Deplores Collapse Of USSR, 25.04.2005, http:// news.bbc.co.uk/2/hi/4480745.stm. 
borders of the new Russian state), anyone can rationally expect Russia to become again overtly expansionist (and, if such behaviour is possible, very aggressive).

Facing such a perspective (which is not at all a strictly theoretical or hypothetical one, if we look carefully at recent events in Chechnya, in Georgia, in Ukraine, and even in Syria), the West, which is directly threatened, in the end, has to react in one way or another. Quite clearly, exactly as in the late 1940s, when Kennan wrote his notorious Long Telegram, Russian aggressiveness has to be 'contained' in one way or another.

In our opinion, the best strategy for achieving such a goal is that of shaping, maintaining, developing and strengthening potent and really credible political and military tools for implementing what is usually called deterrence.

In the very case we are speaking about, in order to deter Russian imperial expansionism (and the already sharply increased Russian strategic aggressiveness in the international arena), the belief in the minds of the Russian decision-makers has to be massively (and as quickly as possible) eroded as well. This belief was openly expressed, more than a decade ago, by Vladimir Putin, on the same occasion used by him to deplore the collapse of the USSR. He said, speaking about his future hopes and plans, "our place in the modern world will be defined only by how successful and strong we are". Success, quite clearly, might be interpreted as a potentially benign concept (speaking, possibly, about success of modernisation, about a larger GDP, etc.) But strong has, frankly speaking, at least in a well-prepared speech, only one possible meaning: strong military capabilities, allowing Moscow to achieve important political goals by means of using military force.

In order to erode the belief that Russia can, in the end, achieve important political (and, in a very broad sense, strategic or geo-strategic) goals by being expansionist again, and by being aggressive again, the West has to accomplish, quite clearly, a goal that is very easy to understand: that of implementing, transparently, but also resolutely and as quickly as possible, policies aimed at telling Russia, directly: You are really stronger than before; but, take care, your strength is clearly not enough either to defeat us, or to really scare us.

In order to deter Russia, NATO is already using significant increases in the field of general military capabilities. The NATO decision to make all member countries 
use not less than $2 \%$ of their GDPs for defence is to generate, most probably mainly over the next decade, some significant results.

'Rotating' NATO military units in countries geographically placed not far away from Russia (in the three small Baltic republics - in Estonia, in Latvia, in Lithuania ${ }^{14}$, but also in Poland, in Romania and in Bulgaria) is another potentially effective tool, a 'dual use' one: militarily speaking, it extensively tests and consolidates interoperability, plus it makes military contingents belonging to different Western nations become more familiar with the general conditions of a possible area of open confrontation on the Eastern borders of NATO; politically speaking, its significance is also obvious: such a move proves, to anyone concerned, that NATO really has the political will to defend, if necessary, its smaller members on its outer rim directly facing Russia.

Buying and integrating within already existing military structures of a conventional nature (the regular armed forces) new weapons and weapons systems is also to be taken into account, in several countries ${ }^{15}$. As far as we know - and we will use only open sources here - several countries on the so-called Eastern Flank of the Alliance are already involved, at different stages, in the process of getting new military hardware. If we are to list some of the more recent and really significant pieces of news connected to this topic, we know, for example, about the Polish intention to buy several Patriot missile defence ${ }^{16}$ systems; and about Estonia's intention to buy $155 \mathrm{~mm}$ self-propelled howitzers, produced in South Korea ${ }^{17}$. In the Black Sea area, Romania is also buying modern weapons, in order to significantly boost

14 For the deployment of German military units in Lithuania, for example, see Hundreds Of German Soldiers Prepare To Deploy To Baltics For NATO, 19.01.2017, http://www.dw.com/ en/hundreds-of-german-soldiers-prepare-to-deploy-to-baltics-for-nato/a-37201832.

15 For the special situation of Poland, for example, the need to buy modern weapons was recently explored in a text published by the Atlantic Council: Gen. Sir R. Shirreff, M. OlexSzczytowski, Arming For Deterrence: How Poland And NATO Should Counter A Resurgent Russia, 2016.

16 In July 2017, Jerusalem Post was reporting it is a "deal worth close to $\$ 8$ billion" - see A. Ahronheim, Poland To Buy Israeli-Made Patriot Missiles, 10.07.2017, http://www.jpost. com/Israel-News/Poland-to-buy-Israeli-made-Patriot-missiles-499233.

17 J. Adamowski, Estonia Joins Finland In Howitzer Procurement, 6.02.2017, https:// www.defensenews.com/land/2017/02/06/estonia-joins-finland-in-howitzer-procurement/. The piece of news we are quoting here from was also stating "Estonia's decision to acquire new ground warfare weapons reflects the increased concern of the three Baltic states over what they consider Russia's belligerent behavior in Eastern Europe". 
its defensive capabilities, almost directly threatened by the increased Russian aggressiveness, and by Russian actions aimed at sharply increasing its military capabilities in the region: in April 2017, officials in Bucharest declared Romania's intention to buy "the Patriot missile defence system"18. A few months later, in July, the U.S. "State Department cleared the sale of seven Patriot missile defence systems for Romania" (and this decision took place "just days after" U.S. officials had had announced "a roadmap forward for landing the system in Poland" as well) ${ }^{19}$. Four days later, Romanian President Klaus Johannis told journalists, speaking directly about these new military purchases: "We are not getting ready to attack anyone... They are meant to defend us, to guarantee the security of Romanians"20.

\section{Using traditional, but effective tools: the logic of building and consolidating strong popular militias}

In spite of reinforcing U.S. troops deployed (many of these units on a rotational basis) to Europe, and in spite of organising several large and complex (and many smaller ones) military exercises, the total amount of forces NATO already has on its Eastern borders is, at almost any given moment, smaller than the resources Russia might be able to easily concentrate. Let's look at this in a more detailed way. NATO is, demographically, and at economic level, and in terms of military power, significantly stronger than the Russian Federation. In order to better understand this basic truth, it is completely sufficient to underline that Russia has, at this very moment, a total population of roughly 142 million people ${ }^{21}$, while NATO's demographic resources are significantly larger: the United States of America,

18 R.-S. Marinas, Romania Intends To Buy Patriot Missiles From U.S. To Boost Defences, 20.04.2017, https://www.reuters.com/article/romania-usa-patriot/romania-intends-to-buypatriot-missiles-from-u-s-to-boost-defences-idUSL8N1HS4FO.

19 A. Mehta, Romania Cleared To Buy Patriot Missile Defense System, 11.07.2017, https:// www.defensenews.com/global/europe/2017/07/11/romania-cleared-to-buy-patriotmissile-defense-system/.

20 L. Ilie (reporting), S. Powell (editing), Romania Says Any Patriot Missile System Buy Meant To Boost Defense, 15.07.2017, https://www.reuters.com/article/us-romania-defense/ romania-says-any-patriot-missile-system-buy-meant-to-boost-defense-idUSKBN1A00EE. 21 Russia, in "The World Factbook", 2017, https://www.cia.gov/library/publications/theworld-factbook/geos/rs.html. 
alone, is a country more than twice as big, in strictly demographic terms (with its 326.6 million inhabitants ${ }^{22}$ ), than the Russian Federation. The same situation is true if we are speaking about economic resources, expressed, for example, by the Gross Domestic Product (GDP). At this very moment, according to estimated figures quite recently made public by the CIA, the total Russian GDP is $\$ 3.751$ trillion (2016 estimate), while the U.S. GDP is 18.57 trillion (2016 estimate), more than four times larger than the Russian one. Many other reliable open sources also indicate that Russia is significantly weaker, economically speaking, than NATO (and also weaker than the United States, the most important political and military actor within NATO). For example, a text made public in late autumn 2016 openly stated that: "Russia's economy is roughly a tenth the size of the U.S."' ${ }^{23}$. If we are speaking about military budgets, the general situation is almost the same: in a very broad sense, Russia is clearly weaker than NATO (and above all, obviously weaker than the United States). The evaluation published by Geopolitical Futures and already quoted a few lines above says "according to the Stockholm International Peace Research Institute, U.S. military expenditure in 2015 was 3.3 percent of GDP, and Russia's was 5 percent of its GDP", and the available data places "Russia among the top five military spenders in the world, but in absolute terms it means Russia's military expenditure adds up to roughly 10 percent of U.S. military spending" ${ }^{24}$.

This broad picture is not necessarily generating a lot of political and strategic optimism in the countries on the Eastern rim of NATO, because of a very simple reason: even if NATO is significantly stronger than Russia, the Russian Federation is simply almost dwarfing any NATO country along the general line connecting the Baltic and the Black Sea (and also all these countries put together, if we focus our attention on certain relevant data and figures). For example, at this very moment, the total Russian population, even if it is several times smaller than the total demographic resources of NATO, is clearly greater than the total demographic resources of the three small Baltic states, Poland, and Romania, put together

22 United States, in “The World Factbook", 2017, https://www.cia.gov/library/publications/ the-world-factbook/geos/us.html.

23 J.L. Shapiro, A Tale of Two Economies, 29.11.2016, https://geopoliticalfutures.com/atale-of-two-economies-russia-and-the-us/.

24 Ibid. 
(more than 140 million Russians, and only about 38.5 million Poles ${ }^{25}$, 21.5 million Romanians $^{26}$, almost 1.95 million Latvians ${ }^{27}$, 2.82 million Lithuanians ${ }^{28}$, and 1.25 million Estonians ${ }^{29}$ ). All these figures, put together, point to the total population of Russia being almost 3.7 times larger than that of Poland; more than 6.6 times larger than that of Romania; more than 70 times larger than that of Latvia; more than 50 times larger than that of Lithuania; and almost 114 times larger than the total population of the demographically tiny Estonia.

In such a situation, the question all the NATO countries on the Eastern rim of the Alliance (those geographically placed on the shores of the Baltic and between the Baltic and the Black Sea) are confronted with is clearly a difficult one: in which way might some political entities, each of them (and even all of them put together) demographically smaller then Russia, with GDPs smaller than that of Russia, and with national armed forces clearly smaller than those of the Russian Federation, have a really decent chance of deterring - or stopping, if necessary, perfectly plausible (and, according to many professional opinions, probable) more or less overt Russian aggression?

One of the most potent potential answers to such a question is, in our professional opinion, that of implementing, in each of these countries, a significant amount of extra military strength \& extra strategic resilience, and of openly showing a significant amount of coherent political will, by means of quickly developing and consolidating a large system of territorial defence forces or popular militias.

Most obviously, no one can rationally expect popular militias, even if they might be well trained and well-armed and equipped, and also at least decently logistically supported, to stop and/or defeat a possible Russian attack in the open field. But the most important significance of such militias (an institution, let us not forget,

25 Poland, in "The World Factbook", 2017, https://www.cia.gov/library/publications/theworld-factbook/geos/pl.html.

26 Romania, in "The World Factbook", 2017, https://www.cia.gov/library/publications/ the-world-factbook/geos/ro.html.

27 Latvia, in "The World Factbook", 2017, https://www.cia.gov/library/publications/theworld-factbook/geos/lg.html.

28 Lithuania, in "The World Factbook", 2017, https://www.cia.gov/library/publications/ the-world-factbook/geos/lh.html.

29 Estonia, in "The World Factbook", 2017, https://www.cia.gov/library/publications/theworld-factbook/geos/en.html. 
with strong roots in European history) is not strictly at military level. Establishing, training, arming and consolidating strong popular militias in any of the countries of the Eastern rim of NATO might generate, first of all, an immensely powerful message Moscow cannot ignore: this message is openly saying "our political will is not going to falter, and Russia will be confronted, if it invades us, not only by the regular armed forces, but by our entire nation".

Most probably, Russia might hope its elite military units (possibly enjoying temporary, but clear superiority in manpower) might have some chance of overcoming, defeating or suppressing most of the regular military resistance of one or several small(er) NATO countries on the Eastern rim of the Alliance, before NATO might react with full force (according to the logic of Article 5 of the NATO Treaty. But in any set of circumstances, we can imagine, Russia has no real hope of putting an end to the political will embodied by really strong popular militias, if they do exist.

Such a statement obviously needs some extra explanation. We are to remember, for example, that on several occasions, until the final years of that war, the regular British forces sent to invade and defeat the 13 American colonies fighting for independence, in the $18^{\text {th }}$ century, managed to defeat the regular U.S. forces. But the political will of the American nation, and its direct military consequence - the very existence of a large, resolute and broadly effective system of popular militias -never faltered, and on many occasions such militias were able to either defeat the British 'redcoats', or to make them pay a clearly prohibitive military price (see, for example, the notorious case of the battle at Lexington and Concord ${ }^{30}$, or that of the battle at Bunker Hill $\left.{ }^{31}\right)$. Such examples were replicated later on, on many other occasions, in several important military confrontations in the international arena (see, for example, the effectiveness of the Boer popular militias fighting, in the opening stages of the $20^{\text {th }}$ century, against the vastly superior British army ${ }^{32}$;

30 G. Perret, A Country Made By War: From The Revolution To Vietnam - The Story Of America's Rise To Power, 1989, pp. 3-10 (according to this text, at the end of the first day of fighting, the British regulars had had lost 65 dead, 180 wounded, and 28 missing, while the American militia casualties were significantly smaller - 49 dead, and more than 41 wounded).

31 Ibid., p. 16 (again, British casualties were significantly larger than those of the American popular militias).

32 Field Marshall Lord Carver, Britain's Army In the Twentieth Century, 1998, pp. 1-6. 
or the effectiveness of popular militias, or partisans, in the Balkans during the Second World War, also fighting against vastly superior forces ${ }^{33}$; or, even more recently, how, in spite of their structural weaknesses, the various local tribal - or popular - militias fighting against the Soviets, in Afghanistan, in the 1980s were so obviously effective ${ }^{34}$ ).

Most obviously, operating a system of popular militias within the framework of a larger effort aimed at deterring Russian aggression is not at all to be regarded as an omnipotent medicine, able to instantly cure all strategic problems. Such a system might be confronted with a lot of troubles and problems of all sorts. But, in the end, a strong system of popular militias, in all the countries now directly threatened by increased aggressiveness of the Putin regime, might be a strong extra strategic deterrent against Russian aggressiveness. And, above all, we are speaking about a system which can be implemented quite soon, and with moderate costs. As far as official documents and open sources indicate, at least in some countries directly threatened by Russia, some significant steps have already been taken in the general direction of forging potent popular militias. In March 2017, for example, an open source spoke about a sharp increase in the number of volunteers in the Lithuanian popular militias, a move which "is a real matter of concern among Russian defence experts" ${ }^{\prime 35}$. And, in Poland, an important official document stated, in May 2017, that "the newly-established Territorial Defence Forces, trained to neutralise hostile activities below the threshold of an armed conflict, will play a supportive role" ${ }^{36}$, augmenting the fighting capabilities of the regular army. The same document also addressed the "new forms of short-term military training, which will be based on volunteers" ${ }^{\prime 37}$.

In the end, popular militias might wage, if necessary, a special type of "irregular warfare" against any invaders (Russians included), and very serious recent works

33 W. Churchill, Al Doilea Război Mondial [The Second World War], 1996, vol. 2, pp. 290-295.

34 S.G. Jones, In The Graveyard Of Empires: America's War in Afghanistan, 2009, 2010, pp. 18-43.

35 P. Goble, Lithuanian Popular Militia Expands to Defend Against Russian Threat, in "Eurasia Daily Monitor", 7.03.2017, https://jamestown.org/program/lithuanian-popularmilitia-expands-defend-russian-threat/.

36 Ministry of National Defence, The Concept Of Defence Of The Republic Of Poland, May 2017, p. 7.

37 Ibid., p. 48. 
openly state that "when statesmen and their military and intelligence services dismiss the capabilities of such irregular adversaries as primitive, and fail to plan appropriately, catastrophe ensues"38.

\section{Bibliography}

Adamowski J., Estonia Joins Finland In Howitzer Procurement, 6.02.2017, https:// www.defensenews.com/land/2017/02/06/estonia-joins-finland-in-howitzerprocurement/.

Ahronheim A., 10.07.2017, Poland To Buy Israeli-Made Patriot Missiles, http://www. jpost.com/Israel-News/Poland-to-buy-Israeli-made-Patriot-missiles-499233.

Bugajski J., Cold Peace: Russia's New Imperialism, 2004.

Carver Field Marshall Lord, Britain's Army In the Twentieth Century, 1998.

Churchill W., Al Doilea Război Mondial [The Second World War], 1996.

Dufour J.-L., Crizele Internaționale De La Beijing (1900) La Kosovo (1999) [International Crises From Beijing (1900) To Kosovo (1999)], 2002.

Goble P., Lithuanian Popular Militia Expands to Defend Against Russian Threat, in “Eurasia Daily Monitor”, 7.03.2017, https://jamestown.org/program/lithuanianpopular-militia-expands-defend-russian-threat/.

Gorbachev Criticises Russian Policy in Chechnya, 4.12.1999, http://news.bbc.co.uk/2/hi/ europe/549638.stm.

Ilie L. (reporting), Powell S. (editing), Romania Says Any Patriot Missile System Buy Meant To Boost Defense, 15.07.2017, https://www.reuters.com/article/us-romaniadefense/romania-says-any-patriot-missile-system-buy-meant-to-boost-defenseidUSKBN1A00EE.

Jones S.G., In The Graveyard Of Empires: America's War in Afghanistan, 2009, 2010.

Marinas R.-S., Romania Intends To Buy Patriot Missiles From U.S. To Boost Defences, 20.04. 2017, https://www.reuters.com/article/romania-usa-patriot/romania-intendsto-buy-patriot-missiles-from-u-s-to-boost-defences-idUSL8N1HS4FO.

Mehta A., Romania Cleared To Buy Patriot Missile Defense System, 11.07.2017, https:// www.defensenews.com/global/europe/2017/07/11/romania-cleared-to-buy-patriotmissile-defense-system/.

Ministry of National Defence, The Concept Of Defence Of The Republic Of Poland, May 2017.

38 R.H. Shultz Jr., A.J. Dew, Insurgents, Terrorists, And Militias: The Warriors Of Contemporary Combat, 2006, p. 260. 
Perret G., A Country Made By War: From The Revolution To Vietnam - The Story Of America's Rise To Power, 1989.

Shapiro, J. L., A Tale Of Two Economies, 29. 11. 2016, https://geopoliticalfutures.com/atale-of-two-economies-russia-and-the-us/.

Shirreff Gen. Sir R., Olex-Szczytowski M., Arming For Deterrence: How Poland And NATO Should Counter A Resurgent Russia, July 2016.

Shultz R.H.Jr., Dew A.J., Insurgents, Terrorists, And Militias: The Warriors OfContemporary Combat, 2006.

Schultz T., NATO Voices Skepticism Over Size Of Russia's Zapad Military Exercise, http://www.dw.com/en/nato-voices-skepticism-over-size-of-russias-zapad-militaryexercise/a-39682346, [accessed: 14.09. 2017].

Strategic Concept For the Defence and Security of The Members of the North Atlantic Treaty Organisation. Adopted by Heads of State and Government in Lisbon, 2010, http://www.nato.int/lisbon2010/strategic-concept-2010-eng.pdf.

The Alliance's New Strategic Concept agreed by the Heads of State and Government participating in the Meeting of the North Atlantic Council, 7-8 November 1991, http:// www.nato.int/cps/en/natohq/official_texts_23847.htm, [accessed: 26.08. 2010].

The Alliance's Strategic Concept Approved by the Heads of State and Government participating in the meeting of the North Atlantic Council in Washington D.C.. Press Release NAC-S(99) 65, 24.04.1999, http://www.nato.int/cps/en/natohq/official_texts_ 27433.htm [accessed: 25.06.2009].

"The World Factbook", https://www.cia.gov/library/publications/the-world-factbook/.

Walt S.M., The Origin Of Alliances, 1987.

Westwood, J.N., Endurance And Endeavour: Russian History 1812-1986, third edition 1987, 1988.

Yeltsin Speaks Of Guilt Over Chechnya, 8.10. 2000, http://news.bbc.co.uk/2/hi/ europe/961848.stm.

Zapad-2017 Exercise Puts Russian Army's „Nervous System” To Test, http://tass.com/ defense/966366 [accessed: 19.09. 2017]. 